\section{Standard and Specialized Infant Formulas in Europe: Making, \\ Standard and Specialized Infant F
Marketing, and Health Outcomes}

\author{
Valeria Dipasquale, $\mathrm{MD}^{1}$; Gregorio Serra, $\mathrm{MD}^{2}$; Giovanni Corsello, $\mathrm{MD}, \mathrm{PhD}^{2}$; \\ and Claudio Romano, MD, PhD $^{1}$
}

Nutrition in Clinical Practice Volume 00 Number 0 January 2019 1-9 (c) 2019 American Society for Parenteral and Enteral Nutrition DOI: $10.1002 /$ ncp. 10261 wileyonlinelibrary.com

WILEY

\begin{abstract}
Infant formulas are the only suitable substitute for human milk. The most common infant formulas are standard formulas based on cow's milk. In addition, there are formulas for infants showing signs and symptoms of intolerance and for clinical conditions such as allergy, prematurity, and gastrointestinal diseases. A comprehensive review of the literature was made to review the composition of standard and specialized infant formulas and analyze indications for use, real or presumed nutrition differences and properties, and impact on infant growth. A brief consideration on costs is outlined for each formula. Over the past few years, industrial production and advertising of infant formulas have increased. Human milk still remains the most complete source of nutrition for infants and should be continued according to the current recommendations. Few differences exist between infant formulas, both for the nutrition action and the macronutrient/micronutrient composition. Specialized infant formulas have limited indications for use and high costs. The role of the pediatrician is crucial in the management of infant nutrition, promotion of breastfeeding, and prescribing of specialized formulas only in specific clinical conditions. (Nutr Clin Pract. 2019;00:1-9)
\end{abstract}

\title{
Keywords
}

enteral nutrition; human milk; infant; infant formula; infant nutrition

\section{Introduction}

Human milk is the best source of nutrition for term and preterm infants. It is unmatched and adapts over time to meet the changing nutrition needs for optimal growth and development of the infant. ${ }^{1}$ There seems to exist a relationship between maternal diet and human milk nutrition composition, but it is still an open issue. ${ }^{2}$ The World Health Organization (WHO) established that the ideal feeding pattern for healthy term infants is exclusive breastfeeding for the first 6 months of life and breastfeeding with complementary foods for up to 2 years of age or beyond. ${ }^{3,4}$ Nonetheless, breastfeeding prevalence remains low in the WHO European region: in 2006-2012, only an estimated $25 \%$ of infants were exclusively breastfed for the first 6 months. ${ }^{5,6}$ Infant formulas are substitutes for breast milk. They are mainly categorized into standard and specialized formulas. The most common infant formula is standard formula based on cow's milk. ${ }^{7}$ Specialized infant formula (SIF), or "formula for special medical purposes intended for infants," is designed to satisfy the nutrition requirements of infants with specific medical conditions, including prematurity; allergy; or gastrointestinal, metabolic, or renal diseases. ${ }^{7}$ In the last few years, SIF sales have increased significantly. ${ }^{8}$ In 2003 in Italy, the soy formula consumption rate among 4602 infants was 34\%, hydrolyzed protein formula $21.1 \%$, other animal milks $8.3 \%$, and amino acid mixtures $13 \% .{ }^{9}$ Optimal nutrition is crucial to support growth and development in infancy and can impact later health. ${ }^{10}$ Health outcomes differ substantially for infants who formula feed compared with those who breastfeed (Table 1). ${ }^{11}$ Vitamins and minerals, as well as bioactive ingredients, including nucleotides, long-chain polyunsaturated fatty acids, prebiotics, and probiotics, impact health and health outcomes. The aims of this non-systematic review were to point out the indications for use, definitions, and compositions of standard and specialized infant formulas. A brief consideration on costs is outlined for each formula. Articles published in English from 1998 up

From the ${ }^{1}$ Pediatric Gastroenterology and Cystic Fibrosis Unit, Department of Human Pathology in Adulthood and Childhood "G. Barresi”, University of Messina, Messina, Italy; and ${ }^{2}$ Neonatology and Neonatal Intensive Care Unit, Department of Sciences for Health Promotion and Mother and Child Care, University of Palermo, Palermo, Italy.

Financial disclosure: None declared.

Conflicts of interest: None declared.

Corresponding Author:

Claudio Romano, MD, PhD, Pediatric Gastroenterology and Cystic Fibrosis Unit, Department of Human Pathology in Adulthood and Childhood "G. Barresi," University of Messina, Via Consolare Valeria, 98124, Messina, Italy.

Email: romanoc@unime.it 
Table 1. Human Milk Factors That Reduce Risk of Poor Health Outcomes.

\begin{tabular}{|c|c|c|}
\hline Health Outcomes & Types & Low-Risk Associated Factors and Compounds \\
\hline Infectious morbidity & $\begin{array}{l}\text { Otitis media, lower respiratory tract } \\
\text { infections, gastrointestinal infections }\end{array}$ & $\begin{array}{l}\text { Specific and innate immune factors, such as plasma cells, } \\
\text { immunoglobulins, oligosaccharides, glycoproteins, } \\
\text { glycosaminoglycans; human milk fats }\end{array}$ \\
\hline Metabolic diseases & $\begin{array}{l}\text { Obesity, type } 2 \text { diabetes, high blood } \\
\text { pressure, cholesterols }\end{array}$ & $\begin{array}{l}\text { Long-chain polyunsaturated fatty acids (arachidonic acid, } \\
\text { eicosapentaenoic acid), ghrelin, leptin; adipokines; protein } \\
\text { content; self-regulation of intake by the infant }\end{array}$ \\
\hline Neurodevelopment & $\begin{array}{l}\text { Cognitive development and visual acuity } \\
\text { impairment }\end{array}$ & $\begin{array}{l}\text { Long-chain polyunsaturated fatty acids (docosahexaenoic acid, } \\
\text { arachidonic acid, eicosapentaenoic acid); nucleotides }\end{array}$ \\
\hline Atopic conditions & Asthma, atopic dermatitis & $\begin{array}{l}\text { Specific and innate immune factors, such as oligosaccharides, } \\
\text { cytokines, and immunoglobulins }\end{array}$ \\
\hline Others & Type 1 diabetes; leukemia & $\begin{array}{l}\text { Cow's milk antigen, islet-cell antibodies; specific and innate } \\
\text { immune protective factors against early viral infections } \\
\text { involved in leukemia pathogenesis }\end{array}$ \\
\hline
\end{tabular}

to April 2018 were identified from the Pubmed/Medline (http://www.ncbi.nlm.nih.gov/pubmed/) database using the following main search terms: "infant formula," "standard milk formula," and "specialized milk formula." Intervention trials, reviews, guidelines, meta-analyses, and reference lists of these studies were considered. A systematic approach was not considered for this review because of the limited number of published studies on this topic.

\section{Standard Formulas}

Standard infant formula is "a food which purports to be or is represented for special dietary use solely as a food for infants by reason of its simulation of human milk or its suitability as a complete or partial substitute for human milk."12 Standard infant formula is only for use by healthy infants without unusual medical or dietary problems. In 2005, the European Society for Pediatric Gastroenterology, Hepatology and Nutrition (ESPGHAN) provided proposals on compositional requirements and nutrient levels in infant formulas. ${ }^{13}$ Infant formula shall contain per $100 \mathrm{~mL}$ not $<60 \mathrm{kcal}(250 \mathrm{~kJ})$ and not $>70 \mathrm{kcal}(295 \mathrm{~kJ})$ of energy when mixed to standard dilution $(20 \mathrm{kcal} / 30 \mathrm{~mL})$, and it shall contain per $100 \mathrm{kcal}$ the nutrients, with minimum and maximum levels where applicable. ${ }^{13}$ The reduced bioavailability of nutrients compared with human milk is compensated by the addition of other ingredients. Nonetheless, the benefit of the addition should be demonstrated, since the mere presence of a substance in human milk by itself does not justify its addition to formula. ${ }^{13}$ In the United States, the U.S. Food and Drug Administration states that the addition of further nutrition components to infant formula should be "generally recognized as safe."14 The Committee on the Evaluation of the Addition of Ingredients New to Infant Formula has recommended that "manufacturers must demonstrate that the formula containing the new ingredient is capable of sustaining physical growth and development over 120 days when formula is likely to be the sole source of infant nutrition." 14

The most commonly used infant formula is a standard term infant formula based on cow's milk. ${ }^{15}$ These infant formulas have whey:casein ratios of 60:40, a protein content of $2-2.5 \mathrm{~g} / 100 \mathrm{~mL}$, and a protein/energy ratio of $<3 \mathrm{~g} / 100$ kcal. Unmodified cow's milk contains up to $55 \%-80 \%$ higher levels of protein compared with human milk, ${ }^{16,17}$ so it must be skimmed and diluted to be a suitable basis for infant formula. The "early protein hypothesis" suggests that a dietary protein supply to infants in excess of their metabolic requirements will lead to increased plasma and tissue concentrations of insulin-releasing amino acids and an enhanced secretion of insulin and insulin-like growth factor-1, which in turn will enhance early weight gain, adipogenic activity, and long- term obesity risk. ${ }^{18-20}$ Human milk is the gold standard for infant feeding, and so infant formula manufacturers modify cow's milk to be more like human milk. Cow's milk-based infant formula contains added antibodies, nucleotides, long-chain polyunsaturated fatty acids, prebiotic oligosaccharides, probiotic bacteria, vitamins, minerals, and some bioactive peptides. ${ }^{7}$ Among amino acids, only L-forms may be added, while D-forms are removed, as D-lactic acidosis may occur. All contain iron for iron-deficiency anemia prevention. ${ }^{21}$ Docosahexaenoic acid (DHA) and arachidonic acid (ARA) are added. DHA and ARA are important for regulating growth, inflammatory responses, immune function, vision, and motor and cognitive development in infants. ${ }^{13}$ Their average calorie concentration is $0.64-0.67$ calories $/ \mathrm{mL}^{7}$ Some subcategories of standard term infant formula based on cow's milk are organic and "for breastfeeding supplementation."7 Standard formulas must meet all of the infant formula guidelines and support normal growth. They are suitable as human milk substitutes. Standard infant formulas are available in 3 forms: the powder form, which must be mixed with water before feeding and is the least expensive; the 
concentrated liquid form, which must be mixed with water; and the ready-to-feed form, which requires no mixing and is the most expensive. ${ }^{7}$ The cost of the standard powdered infant formulas ranges between $\$ 0.13$ and $\$ 0.28$ for $100 \mathrm{~mL}$.

\section{Specialized Infant Formulas}

SIF can be defined as "a formula in liquid or powder form, as a substitute for breastmilk or infant formula, specially manufactured to satisfy the special nutritional requirements of newborns/infants with specific disorders, diseases or medical conditions." 22 Hungrier baby and goodnight formulas have been included but cannot be strictly considered SIFs, since they are intended for conditions that may be just a perceived problem. A recent cohort study group analyzing weight and height of 1349 formula-fed infants from birth to 4 months found that no significant relationship between an infant's growth and the specific type of specialized formula exists. ${ }^{23}$ The characteristics of the main SIFs are reported in Table 2.

\section{Infant Formulas Marketed for "Hungrier Babies"}

Infant formulas for "hungrier babies" are predominantly casein based, with a whey:casein ratio of 20:80. For infants, casein is harder to digest, resulting in slower gastric emptying and likely greater satiety. Otherwise, the nutrition composition of these infant formulas is not so different from that of standard ones, since the slightly higher carbohydrate and protein content is offset by a slightly lower fat content, which maintains the total energy content at recommended levels. ${ }^{24}$ This type of SIF has been designed as an alternative for bottle-fed infants with a "perceived" greater appetite, when it is too early (prior to 16 weeks of life) to introduce infants to solid foods. ${ }^{25,26}$ The only randomized trial investigating the effect of introducing solid foods at 3-4 vs 6 months in 147 predominantly formulafed infants found no effect of the intervention on growth, body composition, and energy or nutrient intake up to 12 months of age. ${ }^{27}$ Nonetheless, early introduction of solid foods has recently been associated with greater probability of later obesity in formula-fed infants, ${ }^{28}$ and this formula may satisfy the infant so that solids can be delayed until appropriate. In conclusion, infant formulas designed for "hungrier babies" are suitable from birth, but the advice of pediatricians should be asked for first. They are only available in Europe. The costs are higher than standard formulas (about $\$ 0.52$ per $100 \mathrm{~mL}$ ).

\section{Goodnight Milks}

The main feature of goodnight milks is the presence of added constituents making them thicker than standard formulas: the addition of rice starch or potato flakes increase viscosity and "satisfaction" for infants. A reduction in the fat supply keeps the total energy content within regulations. No scientific evidences exist regarding the use of these formulas and their usefulness in promoting sleep. ${ }^{24}$ Health benefits and growth outcomes have not been widely investigated yet. Inappropriate use may undermine breastfeeding and cause the development of nursing bottle caries. Supporting data are lacking. In conclusion, goodnight milks are suitable from 6 months of life, but a preliminary assessment by the pediatrician is advisable. They are only available in Europe and are some of the most expensive commonly available infant formulas (about $\$ 2.18$ per $100 \mathrm{~mL}$ ).

\section{Growing-Up and Toddler Milks}

Growing-up and toddler milks are an alternative, or a complement, to whole cow's milk for children from about 1 year of age, although some growing-up milks are suitable from 10 months of age. ${ }^{24}$ Milks for toddlers aged 2-3 years and for young children have recently been introduced on the market. In comparison to cow's milk and infant and follow-on formula, these milks have higher concentrations of vitamins $\mathrm{A}$ and $\mathrm{D}$, iron, and zinc, and are poorer in calcium and protein. Additionally, growing-up and toddler milks have an almost double content of sugar per $100 \mathrm{~mL}$ than cow's milk. Some of the main brands of these products contain vanilla flavoring. Growing-up milks are suitable for toddlers, since they should receive the majority of their nutrients from the other foods in the diet. The European Food Safety Authority has stated that "no unique role of young-child formulas with respect to the provision of critical nutrients in the diet of infants and young children living in Europe can be identified, so that these milks cannot be considered as a necessity to satisfy the nutritional requirements of young children when compared with other foods that may be included in the normal diet of young children." ${ }^{.9}$ No data currently exist on their specific clinical indications and impact on infant growth and development. Growing-up milks represent the fastest developing sector of the infant formula market; they are significantly more expensive than cow's milk (at least 3 times). ${ }^{24}$

\section{Formulas for Specific Symptoms}

Infant colic, reflux, and perceived gastrointestinal concerns have led to the creation and marketing of a category of specific formulas for term infants. ${ }^{15,30}$ The main modifications in these milks include partially hydrolyzed protein with reduced lactose or lactose free and/or added probiotics or rice starch. The average calorie concentration of these products is $0.64-0.67$ calories $/ \mathrm{mL}^{7}$ The whey:casein ratio of these formulas is $20: 80$, and this could explain the slower gastric emptying. Carbohydrates are replaced with rice starch or precooked corn starch to increase viscosity, which further thickens in the acidic environment inside the 
Table 2. Specialized Infant Formulas.

\begin{tabular}{|c|c|c|c|c|c|}
\hline Types of SIF & Indications & $\begin{array}{l}\text { Contraindications } \\
\text { and Concerns }\end{array}$ & $\begin{array}{l}\text { Macronutrients per } \\
100 \mathrm{~mL}\end{array}$ & Characteristics & $\operatorname{Cost}^{\mathrm{a}}$ \\
\hline $\begin{array}{l}\text { Formulas for } \\
\text { "hungrier } \\
\text { babies" }\end{array}$ & $\begin{array}{l}\text { Children }<16 \text { weeks of } \\
\text { life with greater } \\
\text { appetite }\end{array}$ & $\begin{array}{l}\text { Scarce scientific } \\
\text { supporting } \\
\text { evidence }\end{array}$ & $\begin{array}{l}\text { Carbohydrate } 7.7 \mathrm{~g} \\
\text { Fat } 3.1 \mathrm{~g} \\
\text { Protein } 1.6 \mathrm{~g}\end{array}$ & $\begin{array}{l}\text { Protein: intact } \\
\text { cow's milk } \\
\text { protein }\end{array}$ & Medium low \\
\hline $\begin{array}{l}\text { Goodnight } \\
\text { milks }\end{array}$ & $\begin{array}{l}\text { Children }>6 \text { months of } \\
\text { age that need to be } \\
\text { settled at bedtime }\end{array}$ & $\begin{array}{l}\text { Dental caries } \\
\text { Inappropriate use } \\
\text { (more often than } \\
\text { at bedtime) } \\
\text { Scarce scientific } \\
\text { supporting } \\
\text { evidence }\end{array}$ & $\begin{array}{l}\text { Carbohydrate } 8 \mathrm{~g} \\
\text { Fat } 3.5 \mathrm{~g} \\
\text { Protein } 1.6 \mathrm{~g}\end{array}$ & $\begin{array}{l}\text { Protein: intact cow's } \\
\text { milk proteins } \\
\text { Added organic corn } \\
\text { starch, lactose, } \\
\text { rice and } \\
\text { buckwheat flakes }\end{array}$ & High \\
\hline $\begin{array}{l}\text { Growing-up } \\
\text { and toddler } \\
\text { milks }\end{array}$ & $\mathrm{N} / \mathrm{S}$ & $\begin{array}{l}\text { Nutrition properties } \\
\text { in comparison to } \\
\text { cow's milk and } \\
\text { other foods }\end{array}$ & $\begin{array}{l}\text { Carbohydrate } 8.5 \mathrm{~g} \\
\text { Fat } 2.6 \mathrm{~g} \\
\text { Protein } 1.5 \mathrm{~g}\end{array}$ & $\begin{array}{l}\text { Protein: less than } \\
\text { cow's milk } \\
\text { formula } \\
\text { Double content of } \\
\text { sugar per } 100 \mathrm{~mL} \\
\text { than standard } \\
\text { cow's milk }\end{array}$ & Medium high \\
\hline Anti-reflux & $\begin{array}{l}\text { Uncomplicated } \\
\text { gastroesophageal reflux } \\
\text { disease }\end{array}$ & Prematurity & $\begin{array}{l}\text { Carbohydrate } 6.8 \mathrm{~g} \\
\text { Fat } 3.5 \mathrm{~g} \\
\text { Protein } 1.6 \mathrm{~g}\end{array}$ & $\begin{array}{l}\text { Protein: intact cow's } \\
\text { milk protein } \\
\text { Lactose-free or low } \\
\text { content } \\
\text { Contains rice starch }\end{array}$ & Medium low \\
\hline $\begin{array}{l}\text { Lactose-free } \\
\text { formulas }\end{array}$ & $\begin{array}{l}\text { Lactose intolerance } \\
\text { Acute diarrhea in children } \\
\text { with malnourishment } \\
\text { or at risk of } \\
\text { malnutrition }\end{array}$ & Dental caries & $\begin{array}{l}\text { Carbohydrate } 7.4 \mathrm{~g} \\
\text { Fat } 3.6 \mathrm{~g} \\
\text { Protein } 1.4 \mathrm{~g}\end{array}$ & $\begin{array}{l}\text { Glucose as the } \\
\text { primary } \\
\text { carbohydrate }\end{array}$ & Medium low \\
\hline $\begin{array}{r}\text { Premature } \\
\text { formulas }\end{array}$ & $\begin{array}{l}\text { Premature and } \\
\text { low-birth-weight } \\
\text { infants }(<1500 \mathrm{~g})\end{array}$ & $\begin{array}{l}\text { Scarce supporting } \\
\text { evidence for } \\
\text { post-discharge } \\
\text { formulas }\end{array}$ & $\begin{array}{l}\text { Carbohydrate } 8.8 \mathrm{~g} \\
\text { Fat } 4.1 \mathrm{~g} \\
\text { Protein } 2.4 \mathrm{~g}\end{array}$ & $\begin{array}{l}\text { Protein: intact cow's } \\
\text { milk protein } \\
\text { Higher calorie } \\
\text { concentrations }\end{array}$ & Medium high \\
\hline $\begin{array}{l}\text { Partially } \\
\text { hydrolyzed } \\
\text { formulas }\end{array}$ & $\begin{array}{l}\text { Marketed as intolerance } \\
\text { formulas; not truly } \\
\text { hypoallergenic }\end{array}$ & $\begin{array}{l}\text { Cow's milk protein } \\
\text { allergy }\end{array}$ & $\begin{array}{l}\text { Carbohydrate } 7.3 \mathrm{~g} \\
\text { Fat } 3.6 \mathrm{~g} \\
\text { Protein } 1.5 \mathrm{~g}\end{array}$ & $\begin{array}{l}\text { Protein: cow's milk } \\
\text { proteins partially } \\
\text { hydrolyzed in } \\
\text { small peptides }\end{array}$ & Medium low \\
\hline $\begin{array}{l}\text { Extensively } \\
\text { hydrolyzed } \\
\text { formulas }\end{array}$ & $\begin{array}{l}\text { Cow's milk/soy protein } \\
\text { intolerance in } \\
\text { bottle-fed infants } \\
\text { Protein maldigestion } \\
\text { and/or malabsorption }\end{array}$ & Low palatability & $\begin{array}{l}\text { Carbohydrate } 7.5 \mathrm{~g} \\
\text { Fat } 3.4 \mathrm{~g} \\
\text { Protein } 1.9 \mathrm{~g}\end{array}$ & $\begin{array}{l}\text { Protein: cow's milk } \\
\text { proteins further } \\
\text { hydrolyzed in } \\
\text { small peptides }\end{array}$ & Medium high \\
\hline $\begin{array}{l}\text { Amino } \\
\text { acid-based } \\
\text { formulas }\end{array}$ & $\begin{array}{l}\text { More severe cases of } \\
\text { cow's milk/soy protein } \\
\text { intolerance } \\
\text { Intolerance of extensively } \\
\text { hydrolyzed formulas } \\
\text { Protein maldigestion } \\
\text { and/or malabsorption } \\
\text { Gastrointestinal tract } \\
\text { impairment }\end{array}$ & Low palatability & $\begin{array}{l}\text { Carbohydrate } 7.2 \mathrm{~g} \\
\text { Fat } 3.4 \mathrm{~g} \\
\text { Amino acids } 2.1 \mathrm{~g} \\
\quad \text { (equivalent in protein } \\
\quad 1.8 \mathrm{~g} \text { ) }\end{array}$ & Free amino acids & Medium high \\
\hline $\begin{array}{l}\text { Soy-based } \\
\text { formulas }\end{array}$ & $\begin{array}{l}\text { Vegan diet } \\
\text { Family preference } \\
\text { Galactosemia }\end{array}$ & $\begin{array}{l}\text { Prematurity } \\
\text { Colic } \\
\text { Constipation } \\
\text { Cow's milk } \\
\quad \text { protein-induced } \\
\quad \text { enteropathy }\end{array}$ & $\begin{array}{l}\text { Carbohydrate } 7.2 \mathrm{~g} \\
\text { Fat } 3.6 \mathrm{~g} \\
\text { Protein } 1.7 \mathrm{~g}\end{array}$ & $\begin{array}{l}\text { Protein: soy } \\
\text { protein } \\
\text { isolates } \\
\text { All soy formulas } \\
\text { are lactose } \\
\text { free }\end{array}$ & Medium low \\
\hline
\end{tabular}

N/S, not specified; SIF, specialized infant formula.

${ }^{a}$ In comparison to the cost of standard powdered infant formula for use in term infants. 
stomach. Several formulas use carob bean gum, which is not broken down by salivary amylase and thus maintains viscosity. Anti-reflux infant formulas have been designed to help relieve gastroesophageal reflux and vomiting or spitting up in formula-fed infants. These formulas may reduce regurgitations (from 5.43 to 2.50 mean number of regurgitations per day $)^{31-44}$ and seem to allow satisfactory growth. Nonetheless, their use in cases of uncomplicated reflux is not supported by the ESPGHAN Committee on Nutrition, ${ }^{24,45}$ as gastroesophageal reflux does not generally result in adverse health effects and disappears spontaneously by about 3 months of age. ${ }^{24}$ These formulas are similarly priced to standard formulas (about $\$ 0.16$ $\$ 0.24$ per $100 \mathrm{~mL}$ ).

\section{Lactose-Free Infant Formulas}

Lactose is the primary disaccharide in both cow's and human milk. In infants, it is the primary source of the energy necessary to support growth. ${ }^{7}$ The principal difference between lactose free and standard infant formulas based on cow's milk is that in the former, carbohydrate is glucose rather than lactose. Reduced-lactose and lactosefree formulas have been designed for lactose intolerance, which can be due to congenital lactase deficiency (a very rare disorder in infancy) or transient lactose deficiency. ${ }^{24,46}$ In developed countries, the use of lactose-free formula as treatment for acute gastroenteritis has been shown to have no clinical advantage over standard lactose-containing formula. ${ }^{45}$ The use of these formulas for the treatment of acute diarrhea is not supported by the ESPGHAN Committee on Nutrition, ${ }^{24,45}$ with the exception of very malnourished infants. In most cases of transient lactose intolerance due to acute gastroenteritis, it is recommended to stay on human milk or whatever formula the infant was on previously. ${ }^{7}$ In lactose-free formula, the common replacement carbohydrates are cariogenic. ${ }^{24}$ Lactose-free formula may contain cow's milk or soy protein. The absence of lactose in cow's milk-based formula does not adversely affect normal growth in term infants. ${ }^{47}$ In conclusion, lactose-free infant formulas are suitable in transitory and secondary lactose intolerance and for a limited period. The cost of this formula is about $\$ 0.21-\$ 0.26$ per $100 \mathrm{~mL}$.

\section{Premature Formulas}

Premature infant formulas are energy (about 80 $\mathrm{kcal} / 100 \mathrm{~mL}$ ) and protein (up to $2.4 \mathrm{~g} / 100 \mathrm{~mL}$ ) enriched and variably supplemented with minerals, vitamins, and trace elements to sustain intrauterine nutrient accretion rates. They are composed of cow's milk protein and contain higher amounts of calcium and phosphorus. The protein is intact, and whey is predominant. Lactose is the main carbohydrate source, together with some glucose polymers, and medium-chain triglycerides are included. ${ }^{7}$ Premature infant formulas have been conceived to fulfill the growth/development requirements of premature and low-birth-weight infants (infants born weighing $<1500 \mathrm{~g}$ ). ${ }^{7}$ Preterm infants are usually fed with premature formulas before hospital discharge; indeed, these formulas are not commonly indicated for post-discharge feeding (see below). ${ }^{48}$ These formulas are available in ready-to-feed bottles at different caloric concentrations, generally higher than term infant formulas. ${ }^{7}$ The cost per $100 \mathrm{~mL}$ of preterm infant formulas is about $\$ 0.84-\$ 0.93$.

\section{Post-Discharge Formulas}

Post-discharge formulas are specifically designed for preterm infants for 3-12 months post discharge from the hospital. These are energy (about 72-74 kcal/100 mL) and protein (about 1.8-1.9 g/100 mL) enriched and are variably supplemented with minerals, vitamins, and trace elements compared with standard term formulas. The 2016 Cochrane Neonatal Review Group, which reviewed 16 eligible trials with a total of 1251 infant participants, stated that there is limited evidence that post-discharge formulas provide any benefit over formulas for term infants, in terms of both growth parameters (up to 12-18 months post term) and neurodevelopmental outcomes. ${ }^{48}$ On the contrary, premature formula, which is generally licensed and available only for in-hospital use, seems to promote increased weight, length, and head circumference growth up to 12-18 months post term. In conclusion, premature formulas are suitable from birth for premature infants who have higher nutrition requirements than term newborn infants; only the so-called "preterm formula" seems to have actual benefits on short-term linear growth. The cost per $100 \mathrm{~mL}$ of post-discharge infant formulas is about $\$ 0.26-\$ 1.13$.

\section{Partially Hydrolyzed Cow's Milk Formulas}

Partially hydrolyzed formulas (pHF) have been produced with the aim of stimulating the induction of oral tolerance by keeping peptides of sufficient size and immunogenicity. pHF are all modified cow's milk formulas based on $100 \%$ whey protein. Some contain lactose at lower concentrations than standard formulas, structured vegetable oils, nondigestible oligosaccharides, and added starch as thickening agent. They are not considered hypoallergenic, but they are more easily digested by reducing transit time and gastrointestinal distress for infants experiencing fussing, colic, and constipation. ${ }^{7,49}$ pHF are also defined as "comfort milks." Currently, there is insufficient evidence to suggest that $\mathrm{pHF}$ can prevent atopic disease. ${ }^{24} \mathrm{pHF}$ costs range from $\$ 0.20$ to $\$ 0.25$ per $100 \mathrm{~mL}$. 


\section{Extensively Hydrolyzed Cow's Milk Protein Formulas and Amino Acid Formulas}

The extensive hydrolysis of proteins is aimed at neutralizing allergenic epitopes. Extensively hydrolyzed cow's milk protein formulas (eHF) are further hydrolyzed in comparison to $\mathrm{pHF}$ to obtain hypoallergenicity. They are recommended for cow's milk/soy protein intolerance and sensitivity and for gastrointestinal or hepatobiliary disease-related significant malabsorption. ${ }^{50}$ eHF are less palatable than standard formulas. Costs range from $\$ 0.41$ to $\$ 0.90$ per $100 \mathrm{~mL}$.

Amino acid formulas (AAF) are entirely composed of free amino acids. The use of AAF is warranted in more severe cases, such as anaphylaxis, and also in infants who do not tolerate eHF. ${ }^{50-53}$ AAF are also suitable for diseases like protein malabsorption, gastrointestinal tract motility issues, short bowel syndrome, severe food allergies, and eosinophilic gastroenteropathies. ${ }^{53}$ AAF are less palatable and significantly more expensive than standard infant formulas (about $\$ 1.18$ per $100 \mathrm{~mL}$ ).

In infancy, the prevalence of cow's milk protein intolerance is $5 \%-15 \%$, while that of allergy is $2 \%-7.5 \%{ }^{7}$ Infants who have cow's milk protein allergy (CMPA) or sensitivity and are not exclusively breastfed should be given a therapeutic formula that is clinically proven to have reduced allergenicity, in that, with $95 \%$ confidence, it is tolerated by $\geq 90 \%$ of infants with CMPA. Unfortunately, only some eHFs and AAFs in Europe satisfy this principle. An eHF should be considered as the first choice in all cases of CMPA, except the most severe ones, since it is cheaper than AAF and more effective at inducing tolerance. Several studies have demonstrated that hydrolyzed formulas support the normal growth of healthy term infants, also in the first months of life. ${ }^{54-60}$ The risk of having less than the recommended daily intake of calcium and vitamin $\mathrm{D}$ in children with CMPA has been shown to be lower if children consume a cow's milk-free infant formula. ${ }^{61}$

Infant milk formulas from non-bovine animals (goat, ewe, mare, donkey, or camel) have been widely marketed as substitutes for cow's milk, but they are not nutritionally appropriate for infants' needs ${ }^{50}$ and could cause harm, since they carry a high risk (up to $80 \%$ ) of cross-reactivity. In particular, sheep's and goat's milks have a high degree of homology and cross-reactivity to cow's milk, ${ }^{62}$ whereas the risk is lower (but still present) with donkey's and camel's milks. ${ }^{62}$ No robust evidence on their use in the management of CMPA in infants and children exists. ${ }^{50}$

\section{Soy Protein-Based Infant Formulas}

Soy protein-based formula combines protein from soy beans with water, vegetable oils (with added DHA and ARA), glucose syrup (or corn maltodextrin, corn syrup solids, and sucrose), amino acids (L-methionine), vitamins, and minerals. ${ }^{24}$ It is a plant-based formula, and therefore it is whey, casein, and lactose free. ${ }^{5}$ Soy protein-based formulas are recommended for infants with galactosemia and hereditary lactase deficiency and for parents who wish to provide their children with a vegetarian diet. ${ }^{63}$ Soybased formulas in CMPA can be considered when eHF is not tolerated or is rejected by the infant, even though up to $14 \%$ of infants with CMPA will also react to soybased formula because of cross-reactivity. ${ }^{64}$ Multiple studies have confirmed normal growth in term infants but not in preterm infants. ${ }^{46,65}$ Soy protein-based formula is not recommended for preterm newborns, since less weight gain and more osteopenia have been observed. ${ }^{48}$ These formulas contain higher amounts of phytoestrogens than standard formulas. ${ }^{66}$ Evidence on the negative impact of dietary soy isoflavones on reproduction and endocrine function is not conclusive. In conclusion, soy protein-based formulas are suitable from birth in term infants. The cost of soy proteinbased milks is about $\$ 0.25$ per $100 \mathrm{~mL}$.

\section{Rice-Based Formulas}

Rice-based formulas are not recommended for toddlers and young children. Major issues include nutrition appropriateness to the requirements of infants and concentration of inorganic arsenic. ${ }^{67}$ The use of rice-based milks may increase the intake of inorganic arsenic up to 4-fold. Rice-based formulas are available on the European market. Their efficacy in preventing and/or treating CMPA has not been extensively studied. ${ }^{52}$

\section{Infant Milks for Vegetarians and Vegans}

More and more individuals choose a vegetarian or vegan diet over the conventional diet, which includes animal products. Vegetarianism and veganism are losing their marginal feeding position and are becoming more popular. ${ }^{68}$ Parents can guide their children towards this type of diet from the very first years of life, and thus infant milk has been designed for these new tendencies. Infant formula derived from cow's milk are generally not suitable for vegetarians because of the inclusion of fish oils and/or use of the animal source of the enzyme rennet during the manufacturing process. Although vegetarian alternatives are available, manufacturers usually prefer to use rennet to separate curds from whey. ${ }^{24}$ Currently, there are no infant or follow-on formulas available for vegans, as the vitamin D used is sourced from sheep's wool. The only exception is represented by a formula based on soy protein containing a plant-based source of vitamin $\mathrm{D}$, for children from 1 year of age. ${ }^{24}$ Scientific data on safety, suitability, and use are lacking. Their prescription without accurate monitoring of clinical conditions may be responsible for malnutrition and a spectrum of iron, folate, and vitamin $\mathrm{B}_{12}$ deficiencies. These risks must be clarified 
to vegan parents to avoid such clinical evolutions in their children.

\section{Conclusions}

Exclusive breastfeeding represents the ideal feeding pattern for infants. For infants who cannot be breastfed, formulas are an acceptable alternative to provide adequate nutrition. Only a small proportion of infants truly meet the criteria to require SIFs. Neonatologists and pediatricians need to be knowledgeable about these criteria and provide accurate advice. Although previously it was relatively easy to know the components of specialized formulas based on their names, the diversified offering of formulas on the market today can induce confusion both in parents and healthcare providers. Substantial evidence of links between infant nutrition and both early and later health outcomes exists. The choice of an inadequate formula may be associated with nutrition deficiencies, growth failure, and poor neurodevelopmental outcomes. Pediatricians should direct families toward the most suitable formula for their babies, based on current evidence. Finally, they should identify the minority of infants who would benefit from an SIF. Future studies investigating infant health outcomes of each formula are warranted.

\section{Statement of Authorship}

V. Dipasquale, G. Serra, G. Corsello and C. Romano equally contributed to the conception and design of the work; G. Corsello contributed to the design of the research; V. Dipasquale and G. Serra contributed to the acquisition and analysis of the data; G. Corsello and C Romano contributed to the interpretation of the data; and V. Dipasquale and G. Serra drafted the manuscript. All authors critically revised the manuscript, agree to be fully accountable for ensuring the integrity and accuracy of the work, and read and approved the final manuscript.

\section{References}

1. Victora CG, Bahl R, Barros AJ, et al. Breastfeeding in the 21st century: epidemiology, mechanisms, and life-long effect. Lancet. 2016;387(10017):475-490.

2. Bravi F, Wiens F, Decarli A, Dal Pont A, Agostoni C, Ferraroni M. Impact of maternal nutrition on breast-milk composition: a systematic review. Am J Clin Nutr. 2016;104(3):646-662.

3. World Health Organization \& UNICEF, Global Strategy for Infant and Young Child Feeding. Geneva, Switzerland: WHO; 2003.

4. World Health Organization, Essential Nutrition Actions: Improving Maternal, Newborn, Infant and Young Child Health and Nutrition. Geneva, Switzerland: WHO; 2013.

5. Cattaneo A, Burmaz T, Arendt M, et al. 'Promotion of Breastfeeding in Europe: Pilot Testing the Blueprint for Action' Project. Protection, promotion and support of breast-feeding in Europe: progress from 2002 to 2007. Public Health Nutr. 2010;13(6):751-759.

6. Bagci Bosi AT, Eriksen KG, Sobko T, Wijnhoven TM, Breda J. Breastfeeding practices and policies in WHO European Region Member States. Public Health Nutr. 2016;19(4):753-764.
7. Green Corkins K, Shurley T. What's in the bottle? A review of infant formulas. Nutr Clin Pract. 2016;31(6):723-729.

8. Annunziata A, Vecchio R. Functional foods development in the European market: A consumer perspective. JFF. 2011;3(3):223-238.

9. Frongia $\mathrm{O}$, Bellomo AR. Food allergies and intolerance in infants and children. Medico \& Bambino. 2005;24:533-538.

10. Robinson S. Infant nutrition and lifelong health: current perspectives and future challenges. J Dev Orig Health Dis. 2015;6(5):384389.

11. Ip S, Chung M, Raman G, et al. Breastfeeding and maternal and infant health outcomes in developed countries. Evid Rep Technol Assess (Full Rep). 2007;153:1-186.

12. Federal Food, Drug and Cosmetic Act, 412, Title 21, Code of Federal Regulations 2014;106:107.

13. Koletzko B, Baker S, Cleghorn G, et al. Global standard for the composition of infant formula: recommendations of an ESPGHAN coordinated international expert group. $J$ Pediatr Gastroenterol Nutr. 2005;41(5):584-599.

14. Institute of Medicine of the National Academics. Infant Formula: Evaluating the Safety of New Ingredients. Washington, DC: The National Academics Press; 2004.

15. Rossen LM, Simon AE, Herrick KA. Types of infant formulas consumed in the United States. Clin Pediatr (phila). 2016;55(3):278-285.

16. Alexy U, Kersting M, Sichert- Hellert W, Manz F, Schöch G. Macronutrient intake of 3- to 36- month- old German infants and children: results of the DONALD study. Dortmund nutritional and anthropometric longitudinally designed study. Ann Nutr Metab. 1999;43(1):1422.

17. Heinig MJ, Nommsen LA, Peerson JM, Lonnerdal B, Dewey KG. Energy and protein intakes of breast-fed and formula-fed infants during the first year of life and their association with growth velocity: the DARLING Study. Am J Clin Nutr. 1993;58(2):152-161.

18. Koletzko B, Symonds ME, Olsen SF. Programming research: where are we and where do we go from here? Am J Clin Nutr. 2011;94(6 suppl):2036S-2043S.

19. Koletzko B, von Kries R, Closa R, et al. Lower protein in infant formula is associated with lower weight up to age $2 \mathrm{y}$ : a randomized clinical trial. Am J Clin Nutr. 2009;89(6):1836-1845.

20. Koletzko B, Broekaert I, Demmelmair H, et al. Protein intake in the first year of life: a risk factor for later obesity? The E.U. childhood obesity project. Adv Exp Med Biol. 2005;569:69-79.

21. Walter T, Pino P, Pizarro F, Lozoff B. Prevention of irondeficiency anemia: comparison of high- and low-iron formulas in term healthy infants after six months of life. J Pediatr. 1998;132(4):635640 .

22. Tanzania Food, Drugs and Cosmetics (Marketing of Foods and Designated Products for Infants and Young Children) Regulations, 2013. https://extranet.who.int/nutrition/gina/sites/default/files/TZA\%202013 $\% 20$ THE $\% 20$ TANZANIA $\% 20$ FOOD $\% 20$ DRUGS $\% 20$ AND $\% 20$ COSMETIC $\% 20$ REGULATION $\% 20$ FOODS $\% 20$ AND $\% 20$ DESIGNATED $\% 20$ PRODUCTS $\% 20$ FOR $\% 20$ INFANTS $\% 20$ AND $\% 20$ YOUNG\%20CHILDREN\%29\%20REGULATIONS.pdf.

23. Betoko A, Charles MA, Hankard R, et al. EDEN Mother-Child Cohort Study Group. Determinants of infant formula use and relation with growth in the first 4 months. Matern Child Nutr. 2014;10(2):267279 .

24. Crawley H, Westland S. Infant Milks in the UK: A Practical Guide for Health Professionals. London, UK: First Steps Nutrition Trust; 2017.

25. Clayton HB, Li R, Perrine CG, Scanlon KS. Prevalence and reasons for introducing infants early to solid foods: variations by feeding type. Pediatrics. 2013;131(4):e1108-e1114.

26. Brown A, Rowan H. Maternal and infant factors associated with reasons for introducing solid foods. Matern Child Nutr. 2016;12(3):500515 . 
27. Mehta K, Specker B, Bartholmey S, Giddens J, Ho ML. Trial on timing of introduction to solids and food type on infant growth. Pediatrics. 1998;102(3 Pt 1):569-573.

28. Huh SY, Rifas-Shiman SL, Taveras EM, Oken E, Gillman MW. Timing of solid food introduction and risk of obesity in preschool-aged children. Pediatrics. 2011;127:e544-e551.

29. European Food Safety Authority. Scientific opinion on the essential composition of infant and follow-on formulae. EFSA Journal. 2014; 12:3760.

30. Belamarich PF, Bochner RE, Racine AD. A critical review of the marketing claims of infant formula products in the United States. Clin Pediatr (Phila). 2016;55(5):437-442.

31. Salvatore S, Savino F, Singendonk M, Tabbers M, Benninga MA, Staiano A, Vandenplas Y. Thickened infant formula: What to know. Nutrition. 2018;49:51-56

32. Moya M, Juste M, Cortes E, Auxina A, Ortiz I. Clinical evaluation of the different therapeutic possibilities in the treatment of infant regurgitation. Rev Esp Pediatr. 1999;55:219-223.

33. Khoshoo V, Ross G, Brown S, Edell D. Smaller volume, thickened formulas in the management of gastroesophageal reflux in thriving infants. J Pediatr Gastroenterol Nutr. 2000;31(5):554-556.

34. Vanderhoof JA, Moran JR, Harris CL, Merkel KL, Orenstein SR. Efficacy of a pre-thickened infant formula: a multicenter, doubleblind, randomized, placebo-controlled parallel group trial in 104 infants with symptomatic gastroesophageal reflux. Clin Pediatr. (Phila) 2003;42(6):483-495.

35. Vivatvakin B, Buachum V. Effect of carob bean on gastric emptying time in Thai infants. Asia Pac J Clin Nutr. 2003;12(2):193-197.

36. Wenzl TG, Schneider S, Scheele F, Silny J, Heimann G, Skopnik H. Effects of thickened feeding on gastroesophageal reflux in infants: a placebo-controlled crossover study using intraluminal impedance. Pediatrics. 2003;111(4 Pt 1):e355-359.

37. Xinias I, Mouane N, Le Luyer B, Spiroglou K, Demertzidou V, Hauser B, et al. Cornstarch thickened formula reduces oesophageal acid exposure time in infants. Dig Liver Dis. 2005;37(1):23-27.

38. Miyazawa R, Tomomasa $\mathrm{T}$, Kaneko H, Morikawa A. Effect of formula thickened with locust bean gum on gastric emptying in infants. J Paediatr Child Health. 2006;42(12):808-812.

39. Moukarzel AA, Abdelnour H, Akatcherian C. Effects of a prethickened formula on esophageal $\mathrm{pH}$ and gastric emptying of infants with GER. J Clin Gastroenterol. 2007;41(9):823-829.

40. Miyazawa R, Tomomasa T, Kaneko H, Arakawa H, Morikawa A. Effect of formula thickened with reduced concentration of locust bean gum on gastroesophageal reflux. Acta Paediatr. 2007;96(6):910-914.

41. Chao HC, Vandenplas Y. Effect of cereal-thickened formula and upright positioning on regurgitation, gastric emptying, and weight gain in infants with regurgitation. Nutrition. 2007;23(1):23-28.

42. Chao HC, Vandenplas Y. Comparison of the effect of a cornstarch thickened formula and strengthened regular formula on regurgitation, gastric emptying and weight gain in infantile regurgitation. Dis Esophagus. 2007;20(2):155-160.

43. Hegar B, Rantos R, Firmansyah A, De Schepper J, Vandenplas Y. Natural evolution of infantile regurgitation versus the efficacy of thickened formula. J Pediatr Gastroenterol Nutr. 2008;47(1):26-30.

44. Vandenplas Y, Leluyer B, Cazaubiel M, Housez B, Bocquet A. Doubleblind comparative trial with two anti-regurgitation formulae. $J$ Pediatr Gastroenterol Nutr. 2013;57(3):389-393.

45. Aggett PJ, Agostini C, Goulet O, et al. European Society of Pediatric Gastroenterology, Hepatology and Nutrition (ESPGHAN) Committee on Nutrition. The nutritional and safety assessment of breast milk substitutes and other dietary products for infants: a commentary by the ESPGHAN Committee on Nutrition. J Pediatr Gastroenterol Nutr. 2001;32(3):256-258.
46. Bathia J, Greer F. Use of soy protein-based formulas in infant feeding. Pediatrics. 2008;121(5):1062-1068.

47. Lasekan JB, Jacobs J, Reisinger KS, Montalto MB, Frantz MP, Blatter MM. Lactose-free milk protein-based infant formula: impact on growth and gastrointestinal tolerance in infants. Clin Pediatr (Phila). 2011;50(4):330-337.

48. Young L, Embleton ND, McGuire W. Nutrient-enriched formula versus standard formula for preterm infants following hospital discharge. Cochrane Database Syst Rev. 2016;12:CD004696.

49. Alexander DD, Cabana MD. Partially hydrolyzed $100 \%$ whey protein infant formula and reduced risk of atopic dermatitis: a meta-analysis. J Pediatr Gastroenterol Nutr. 2010;50(4):422-430.

50. Vandenplas Y, Abuabat A, Al-Hammadi S, et al. Middle East Consensus Statement on the prevention, diagnosis, and management of cow's milk protein allergy. Pediatr Gastroenterol Hepatol Nutr. 2014;17(2):6173.

51. Sicherer SH. Hypogenicity and efficacy of an amino acid-based formula in children with cow's milk and multiple food hypersensitivities. J Pediatr. 2001;138(5):688-693.

52. Hill DJ, Murch SH, Rafferty K, Wallis P, Green CJ. The efficacy of amino acid-based formulas in relieving symptoms of cow's milk allergy: a systematic review. Clin Exp Allergy. 2007;37(6):808822.

53. Berni Canani R, Nocerino R, Frediani T, et al. Amino acid-based formula in cow's milk allergy: long-term effects on body growth and protein metabolism. J Pediatr Gastroenterol Nutr. 2017;64(4):632638.

54. Borschel MW, Baggs GE, Oliver JS. Comparison of growth of healthy term infants fed extensively hydrolyzed protein- and amino acid-based infant formulas. Nutrients. 2018;10(3).

55. Burks W, Jones SM, Berseth CL, Harris C, Sampson HA, Scalabrin DMF. Hypoallergenicity and effects on growth and tolerance of a new amino acid-based formula with docosahexaenoic acid and arachidonic acid. J Pediatr. 2008;153(2):266-271.

56. Scalabrin DM, Johnston WH, Hoffman DR, P'Pool VL, Harris CL, Mitmesser SH. Growth and tolerance of healthy term infants receiving hydrolyzed infant formulas supplemented with Lactobacillus rhamnosus GG: Randomized, double-blind, controlled trial. Clin Pediatr. 2009;48(7):734-744.

57. Borschel MW, Ziegler EE, Wedig RT, Oliver JS. Growth of healthy term infants fed an extensively hydrolyzed casein-based or free amino acid-based infant formula: A randomized, double-blind, controlled trial. Clin Pediatr (Phila). 2013:52(10):910-917.

58. Borschel MW, Baggs GE, Barrett-Reis B. Growth of healthy term infants fed ready-to-feed and powdered forms of an extensively hydrolyzed casein-based infant formula: A randomized, blinded, controlled study. Clin Pediatr (Phila). 2014;53(6):585-592.

59. Corkins M, Czerkies L, Storm HM, Sun S, Saavedra JM. Assessment of growth of infants fed an amino acid-based formula. Clin Med Insights Pediatr. 2016;10:3-9.

60. Fields D, Czerkies L, Sun S, Storm H, Saavedra J, Sorensen R. A randomized controlled trial assessing growth of infants fed a $100 \%$ whey extensively hydrolyzed formula compared with a caseinbased extensively hydrolyzed formula. Glob Pediatr Health. 2016;3: $1-9$.

61. Christie L, Hine RJ, Parker JG, Burks W. Food allergies in children affect nutrient intake and growth. J Am Diet Assoc. 2002;102(11): $1648-1651$

62. Järvinen KM, Chatchatee P. Mammalian milk allergy: clinical suspicion, cross-reactivities and diagnosis. Curr Opin Allergy Clin Immunol. 2009;9(3):251-258.

63. Kleinman RE, Greer FR, eds. Pediatric Nutrition. 7th ed. Elk Grove Village, IL: American Academy of Pediatrics; 2014. 
64. Agostoni C, Axelsson I, Goulet O, et al. ESPGHAN Committee on Nutrition. Soy protein infant formulae and follow-on formulae: a commentary by the ESPGHAN Committee on Nutrition. $J$ Pediatr Gastroenterol Nutr. 2006; 42(4):352-361.

65. Zeigler RS, Sampson HA, Bock SA, et al. Soy allergy in infants and children with IgE-associated cow's milk allergy. $J$ Pediatr. 1999;134(5):614-622.
66. Upson K, Sathyanarayana S, Scholes D, Holt VL. Early-life factors and endometriosis risk. Fertil Steril. 2015;104(4):964-971.

67. Hojsak I, Braegger C, Bronsky J, et al. ESPGHAN Committee on Nutrition. Arsenic in rice: a cause for concern. J Pediatr Gastroenterol Nutr. 2015;60(1):142-145.

68. Craig WJ. Nutrition concerns and health effects of vegetarian diets. Nutr Clin Pract. 2010;25(6):613-620. 